high latitudes have great disadvantages so far as observations are concerned. The stars have disappeared, to be seen no more for five or six months, and the sun is so near the horizon, owing to its low declination, that the meridian altitude, upon the measurement of which the latitude usually depends, is not high enough to give a satisfactory result, owing to the uncertainties of the refraction correction, and, if a sextant and artificial horizon are used, to the great difficulty in making the observation at such a low altitude, and unavoidable distortion of the sun's image. For good results it is a maxim with geographical surveyors that no altitude should be taken that is less than $25^{\circ}$ or $30^{\circ}$.

A meridian altitude of the sun only a little above $6^{\circ}$ which is what would be observed at the poles on April 6, or between $11^{\circ}$ and $12^{\circ}$, which would be the amount for April 21, would not be likely to furnish a very exact latitude, even if taken with a first-rate instrument under favourable climatic conditions, much less so when these are not favourable and when the observations are made with the small portable instruments which alone can be carried by the explorer on a rapid dash to the pole, when every ounce of weight is a serious consideration.

Dr. Nansen, after leaving the Fram, took with him on his famous sledge journey a small altazimuth, with 4-inch circles, and a pocket sextant with an arc of $1 \frac{3}{4}$ inches radius, both of which, by means of verniers, read to single minutes. It was with the pocket sextant, however, that his farthest north latitude observation was made, using the natural horizon' and he admits that the result cannot be depended upon to a minute or two.

Captain Cagni observed with a sextant, and in referring to his farthest north latitude, which depended upon an altitude of about. $12^{\circ}$, states that he used both the artificial horizon and the natural horizon, which latter was very distinct.

Coming now to the Antarctic regions, Captain Scott's expedition was well provided with instruments, but his highest latitudes on the southern journey were taken with a small theodolite. In the case of this expedition, the dates when the high latitudes were reached were later on in the summer, so that the sun's southern declination, and consequently its meridian altitude, was higher.

This same remark also applies to Mr. Shackleton's recent expedition, for on January 3 , when the last observation on his long journey to the south was made, the sun's meridian altitude was about $25^{\circ} 33^{\prime}$, which resulted in a latitude of $87^{\circ} 22^{\prime}$, the further distance travelled south of this depending for its measurement chiefly on the sledgeometer, which throughout the journey had been found to agree well with the latitudes observed. On his journey Mr. Shackleton used a 3 -inch transit theodolite, reading to single minutes, and the adjustment of which had been thoroughly tested. He also had the advantage of observing on terra firma instead of moving ice, so altogether his resulting latitudes doubtless compare very favourably, as regards accuracy, with those of other polar explorers.

As regards the effect of extreme cold on the refraction correction of the altitude, it may be interesting to note that, for an altitude of $\mathrm{II}^{\circ}$, there is a difference of just above $\mathrm{x}^{\prime}$ for a change of temperature from $+50^{\circ}$ to $-60^{\circ} \mathrm{F}$.

Sextant observations taken with a glass plate artificial on moving ice would be most untrustworthy, for, in addition to the probable sources of error already referred to, there may be slow oscillations of the water, tidal or other, that may affect the level of the reflecting surface considerably.

NO. 208I, VOL. 8I]

\section{CHEMISTRY IN THE SERVICE OF THE STATE.}

$\mathrm{T}$ is generally known in chemical circles that $\mathrm{Sir}$

Edward Thorpe is relinquishing the post of principal chemist at the Government laboratory, which he has so ably held for the last fifteen years. In the closing paragraphs of the present report ${ }^{1}$ he notes that it is the last document of the kind he will have the honour of submitting to the Treasury, and takes the opportunity of directing attention to the great increase which has occurred in the work of the laboratory during the period in question. It appears that the number of samples examined yearly is now more than double what it was fifteen years ago, the actual figures being $76,5^{1} 3$ in the year 1894 , and 176,935 in $1908-9$.

Naturally there is not much of strictly scientific importance to be found in the record of an establishment devoted to "the daily round, the common task" of acting as chemical Abigail to all and sundry Government offices. Yet in its applications of chemical science to civic requirements Sir Edward's department touches the public welfare at many points; and in illustration of this some gleanings from the pages before us are not without interest. For statistics, in which the report abounds, the reader may be referred to the publication itself.

The business of the laboratory is subdivided into three main classes. Articles examined for the two great revenue departments, Customs and Excise, form by far the largest number of samples. A considerable amount of work, however, is submitted by other branches of the executive, especially the Board of Agriculture, the India Office, the Admiralty, the Board of 'Trade, and the Office of Works. Finally, samples, relatively few in number, but important as being objects of dispute in legal proceedings, are referred to the laboratory for examination under the provisions of the Sale of Food and Drugs Act and the Fertilisers and Feeding Stuffs Act.

In its rôle of revenue chemist, the laboratory is required to hold the balance fairly between the $\mathrm{Ex}$ chequer on the one hand and the maker or importer of taxable commodities on the other. Alcoholic liquors, sugar, tobacco, tea, coffee, and chicory naturally furnish the greater number of samples for analysis, since they are the chief dutiable articles in this country. But in safeguarding the revenue derived from these products it is also necessary to analyse numerous other articles; thus the principal chemist remarks that "the duty on chicory involves the examination of many substances botanically allied to it, such as dandelion and burdock roots." Genuine cider, again, is not liable to import duty, but samples are analysed nevertheless; for " if evidence is found that spirit has been added," the cider comes under the tariff as a preparation containing spirit, and is taxed accordingly. It is noted that a large proportion - more than 13 per cent. - of certain beverages sold as temperance drinks contained an excess of alcohol, the quantity ranging from 3 to II per cent. of proof spirit.

Among other miscellaneous matters, an investigation into the character of the spirits usually sold to the labouring populace was undertaken. Such phrases as "adulterated, maddening liquor" are common in the mouth of the well-meaning but uninformed temperance enthusiast. The results of an impartial inquiry, however, lend no support to the charge of adulteration. Samples of whiskey, gin, rum, and brandy were purchased in the ordinary way

1 Report of the Principal Chem'st upon the work of the Government Laboratory for the Year encied March 3I, Igo9. Cd. 477 I. Price $3 d$. 
at public-house bars and retail counters in workingclass neighbourhoods of London and the orincipal towns of the United Kingdom, as well as irom the booths at fairs and markets in West of Ireland districts. "There was no evidence of any deleterious substance or adulteration of any kind," remarks the principal chemist.

The work done for "other Government departments" covered a very wide range of products. From gold-braid to African coinage; from corditejelly to poisoned trout, almost every conceivable variety of article was submitted for analysis. There is an account of feedirg-stuffs sold by a firm of millers, and found to consist wholly of sawdust and gypsum; wherefore the millers were mulcted in heavy penalties. There is a story of " a firm of traders doing a considerable business" who were found practising extensive frauds with postage stamps. "Proof of the fraud was given by one of the chemists of the department, first at the Mansion House, and afterwards at the Old Bailey, where the accused persons were duly convicted and sentenced."

Glimpses of tragedy also appear here and there. Thus we read about the analysis of the air from an underground chamber in which a post-office employé had been asphyxiated; and about the examination of a paint which gave off certain fumes, and apparently brought about, indirectly, the electrocution of a workman.

Foodstuffs, of course, figure largely in the report. As regards imported butter, it would appear that the legal proceedings taken three or four years ago have had a beneficial effect in eliminating much of the adulteration that was then practised. A similar result is also recorded in respect of preservatives in cream.

The foregoing are a few examples indicating the nature of the year's work, though not altogether its scope. Questions of brewing and distilling, the use of duty-free alcohol in manufactures, the purity of tobacco, the sale of patent medicines, the efficacy of sheep-dips, the trustworthiness of disinfectants, the materials used in dangerous industries, water supply, and many similar matters were also dealt with, and are duly chronicled in the report.

In relinquishing his post, Sir Edward Thorpe can look back upon fifteen years of eminently useful service to the State. Large and conflicting interests are involved in the duties of his department; and to have held the scales evenly between the claims of the public services on the one hand, and the various sections of the trading community on the other, is no mean achievement. One question, however, suggests itself at this juncture. Is it any longer of public utility to retain the present grouping of what are really several laboratories under one head? Looking at what is done in other countries, should not the Board of Agriculture, for example, have its own separate chemical establishment, with a freer hand for investigation and development than is readily practicable under the present conditions?

C. S.

THE BRITISH ASSOCIATION AT WINNIPEG.

GUBJOINED is a synopsis of grants of money appropriated for scientific purposes by the general committee at the Winnipeg meeting. The names of members entitled to call on the general treasurer for the grants are prefixed to the respective research committees.

\section{Recommended by Council.}

Gill, Sir D.-Measurement of Arc in South Africa ... Glazebrook, Dr. R. T.-Electrical Standards Report .... 100 NO. 208I, VOL. 8I]
Section A.-Mathematical and Physical Science. $£$ Turner, Prof. H. H.-Seismological Observations ...... 60 Shaw, Dr. W. N.-Upper Atmosphere .................. 25 Preece, Sir W. H.-Magnetic Observations at Falmouth

Gill, Sir David-Establishing a Solar Observatory in Australia

Section B.-Chemistry.

Divers, Prof. E.-Study of Hydro-aromatic Substances 25 Armstrong, Prof. H. E.-Dynamic Isomerism .......... Kipping, Prof. F. S.-Transformation of Aromatic Nitramines

Kipping, Prof. F. S.-Electro-analysis

Section C.-Geology.

Harker, Dr. A.-Crystalline Rocks of Anglesey .......... Gregory, Prof. J. W.-Faunal Succession in the Carboniferous Limestone in British Isles ............. Tiddeman, R. H.-Erratic Blocks ............................. Lapworth, Prof. C.-Palæozoic Rocks

Watts, Prof. W. W.-Composition of Charnwood Rocks

Watts, Prof. W. W.-Igneous and Associated Sedimentary Rocks of Glensaul ...........................

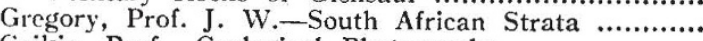
Geikie, Prof.-Geological Photographs ..................... Strahan, Dr. A.-Fossils of Midland Counties ........... Section D.-Zoology.

Woodward, Dr. H.-Index Animalium .................... Hickson, Prof. S. J.-Table at the Zoological Station at Naples

Herdman, Prof. W. A...................................... 75

Shipley, A. E.-Feeding Habits of British Birds ....... Vincent, Dr. Swale-Prairie Fauna ........................

Section F.-Economic Science and Statistics.

Palgrave, R. H. Inglis-Gold Coinage in Circulation in the United Kingdom

Cannan, Prof. E.-Amount and Distribution of Income Section G.-Engineering.

Preece, Sir W. H.-Gaseous Explosions Section H.-Anthropology.

Munro, Dr. R.-Glastonbury. Lake Village ..............
Myres, Prof. J. L.-Excavations on Roman Sites in Britain

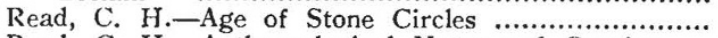

Read, C. H.-Anthropological Notes and Queries.......

Hogarth. D. G.-Researches in Crete ....................

Ridgeway, Prof. W.-Neolithic Sites in Greece ...........

Section I.-Physiology.

Schafer, Prof. E. A.-The Ductless Glands ............

Sherrington, Prof. C. S.-Body Metabolism in Cancer

Hickson, Prof. S. J.-Table at the Zoological Station at Naples

Waller, Dr. A. D.-Electromotive Phenomena in Plants

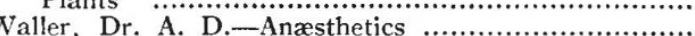

Starling, Prof. E. H.-Tissue Metabolism ..................

Sherrington, Prof. C. S.-Mental and Muscular Fatigue

Starling, Prof. E. H.-Dissociation of Oxy-hæmoglobin

Section K.-Botany.

Scott, Dr. D. H.-Structure of Fossil Plants ........... Io

Darwin, Dr. F.-Experimental Study of Heredity...... 30

Blackman, Dr. F. F.-Symbiosis between Turbellarian

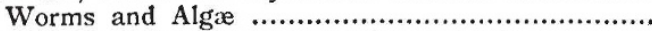

Johnson, Prof. T. - Survey of Clare Island .................. 30

$$
\text { Section L.-Education. }
$$

Magnus, Sir P.--Studies suitable for Elementary Schools .......................................................

Corresponding Societies Commitiee.

Whitaker, W.-For Preparation of Report .............. 20

Total .......................... $\overline{1249}$ 